\title{
The Implementation of Brief-ACT in a Group Setting to Reduce Body Dissatisfaction among Young Adult Women
}

\section{Vitriyanti Sukarno Karyo ${ }^{a}$ and Dini Rahma Bintari ${ }^{\mathrm{b}}$}

${ }^{a}$ Faculty of Psychology, Universitas Indonesia, Depok, Indonesia; ${ }^{b}$ Department of Clinical Psychology, Faculty of Psychology, Universitas Indonesia, Depok, Indonesia

*Corresponding author:

Dini Rahma Bintari

Department of Clinical Psychology

Faculty of Psychology, Universitas Indonesia Jl. Lkr. Kampus Raya, Depok, Jawa Barat Indonesia, 16424

Tel.: +62 217270004

Email address: dini.rahma@ui.ac.id 


\title{
The Implementation of Brief-ACT in a Group Setting to Reduce Body Dissatisfaction among Young Adult Women
}

\begin{abstract}
Body dissatisfaction is a problem that disrupts various areas of an individual's life and causes psychological effects that may lead to malfunction in some areas of life. Body dissatisfaction itself is a trajectory that begins in adolescence and peaks in early adulthood. Emerging adulthood is typically the period of life in which individuals begin to choose romantic partners and start marital life, and in romantic relationships, body shape is often associated with sexual attractiveness. Young adult women who are less satisfied with their body shape consider themselves less attractive, a perception that may make it difficult to find a life partner. In a previous study, Brief-ACT was effective in reducing anxiety related to body and weight. We undertook a non-experimental pre- and post-test study using the Physical Appearance and Traits Scale to measure the body anxiety level before and after the intervention. The participants of this study were young adult women studying at Universitas Indonesia. The implementation of Brief-ACT intervention was conducted in group settings. The study found that Brief-ACT in a group setting could decrease body dissatisfaction in young adult women. Among five participants, a significant decline was seen in two, and a moderate decline was seen in one, with the other two showing a negligible decline. From this we concluded that Brief-ACT in a group setting could lower body dissatisfaction in young adult women. This intervention was effective to be used among participants with above-average BMI as well as with minimal early moderate anxiety levels.
\end{abstract}

Keywords: body dissatisfaction, early adulthood, Brief-ACT, groups

\section{Introduction}

Body dissatisfaction can disrupt many areas of an individual's life and can cause psychological effects such as depressive symptoms, anxiety, and malfunction in certain areas of life (Pearson \& Follette, 2009; Bucchianeri \& Neumark-Sztainer, 2014). Body dissatisfaction is also known to be a predictor of eating disorders and reluctance to eat, mediated by low self-esteem (Jonstang, 2009). Moreover, it can lead to extreme actions that can threaten life (Blashill, Williams, Grogan, Clark-Carter, 2015).

An earlier longitudinal study found that body dissatisfaction itself is a trajectory that begins in adolescence and peaks in early adulthood (Bucchianeri, Arikian, Hannan, Eisenberg, \& Neumark-Sztainer, 2013). Grogan (2016) mentioned body image as the way a person perceives, thinks, and feels his or her body. Grogan's definition included elements in body image described by Schilder (1950) as an estimation of body size, the mind or thinking as an evaluation of the attractiveness of the body, and feeling as the emotion toward form and body size.

Body dissatisfaction is a psychological phenomenon significantly influenced by social factors. Age, ethnicity, socio-economic status, sexuality (related to sexual attractiveness), media exposure to the ideal image, family and friends (comparing body shapes), and BMI have been 
identified as factors that can trigger body dissatisfaction (Quick, Eisenberg, Bucchianeri, \& Neumark-Sztainer, 2013; Grogan, 2016). It could be said that body image dissatisfaction is a complex collision of a negative evaluation of someone's weight and shape (Pearson, Heffner, \& Follette, 2010). Niide et al. (2011) and Showers \& Larson (1999) define body dissatisfaction as a result of a discrepancy between a person's perception of his or her body and an idealized body shape. Body dissatisfaction can have a significant impact on women's behavior, leading them to seek to change their shape and body size (Grogan, 2016).

From the age of 20 to 30 years old, the young adult begins to build self-reliance personally and economically, think about his/her career, choose a partner, and start married life and parenthood. One developmental task in this stage is choosing a partner. Body shape is often associated with sexual attractiveness (Grogan, 2016), and young adult women who perceive that their body shape is unsatisfying consider themselves less attractive, potentially making romantic relationships difficult. Erickson (1975) described early adulthood as a stage of "intimacy vs. isolation" in which individuals begin to develop a commitment with others; a strong personal identity is thus essential for developing intimate relationships. A low sense of self is associated with low commitment in relationships, higher emotional distress, loneliness, and depression. The less sexually attractive a person perceive himself/herself, the lower sense of self they possess. Conversely, someone who passes this stage will more likely have the ability to build a long and meaningful intimate relationship.

Acceptance and Commitment Therapy (ACT) is a therapeutic technique that has components of "accept," "choose," and "take action." ACT aims to develop "acceptance" of a condition or event that was previously avoided and full awareness of making a commitment to take action to achieve a better life (Pearson, Heffner, \& Follette, 2010). ACT uses an acceptance and mindfulness process as well as commitment and behavior change to produce greater psychological flexibility (Hayes, Strosahl, \& Wilson, 2003; Palmeira, Pinto-Gouveia, \& Cunha, 2017). Hayes, Strosahl, and Kirk (2004) describe psychological flexibility as the central core of ACT focusing on the following five core processes: acceptance, diffusion, self as context, contact with the present moment, values, and commitment to action. Each process helps change or persistence to seek or choose value. The goal of ACT is not to build new beliefs but to build a more effective approach through language itself (Hayes \& Strosahl, 2004). ACT can be applied in both individual and group sessions (Pearson, Heffner, \& Follette, 2010). A meta-analysis found that ACT has the same effectiveness in overcoming psychological problems as psychological interventions such as CBT, TAU, and others (Powers, Zum Vorde Sive Vording, \& Emmelkamp, 2009). Nevertheless, research about the effectiveness of ACT in handling body dissatisfaction problems is still limited. Pearson and Follete (2009) found that Brief-ACT was effective to reduce anxiety in relation to body and weight-related distress.

Individuals in groups can be understood through the dynamic interaction between members of the group itself and how they are generated from specific patterns of communication, dynamics, hierarchy, and unique homeostatic systems (Agazarian, 2008; Connors \& Caple, 2005; Napier \& Gershenfeld, 2004 in Neukrug, 2013). Group intervention is defined as a 
meeting of two or more people for a specific therapeutic purpose to achieve a specific goal (Substance Abuse and Mental Health Services Administration, 2012). Group interventions are similar to individual interventions in which each member has the opportunity and freedom to convey their feelings and to change his or her behavior (Neukrug, 2013). Group interventions have some advantages over individual interventions as follows: they are cost-effective, provide opportunities for the participants to learn from other members, for support from group members, and for exposure to social interactions within the group, as well as increase the participants' motivation to follow the intervention (Pearson, Heffner, \& Follette, 2010).

This study aimed to replicate the ACT model from Pearson and Follete (2009) by modifying the meetings. While Pearson and Follett conducted the activity in the form of a one-day eighthour workshop, we held four sessions divided into three face-to-face 90-minute meetings. Based on the success of previous research, we hypothesized that four sessions of Brief-ACT in a group setting would also succeed in decreasing body dissatisfaction levels among young adult women.

\section{Methods}

\section{Participants}

We designed this group intervention for the following five people: two undergraduate students and three master students who met the criteria of experiencing body dissatisfaction.

\section{Measurement}

As did Pearson and Follete (2009), we used the Physical Appearance and Traits Scale (PASTAS-S) to measure the level of body dissatisfaction. PASTAS-S consists of 15 selfreported items and has good validity and reliability to measure the level of anxiety about one's body (Reed, Thompson, Brannick, \& Sacco, 1991; Pearson, Follette, \& Hayes, 2012). This screening tool measures anxiety related to specific body parts such as the hips, legs, and arms. PASTAS-S, which uses a Likert scale in which " 0 " indicates "no anxiety at all" and "4" indicates "very anxious," was chosen because it measures the "current" assessment of the body. Because PASTAS-S itself has never been adapted to an Indonesian version, after translating it to Bahasa Indonesia, we conducted a trial test. In spite of that, validity testing using concurrent validity was also performed with the Body Uneasiness Test-A (BUT-A) as a criterion. Concurrent validity was one type of criterion-related validity test that used a criterion that measures the same construct (Kerlinger \& Lee, 2000). We chose BUT-A because it also measures body dissatisfaction.

BUT-A is a tool developed by Cuzzalaro, Vetrone, Marano, and Garfinkel (2006) and was adapted by Jannah in 2016. It consists of 34 items divided into the following five factors: weight phobia, body image concerns, avoidance, compulsive self-monitoring, and depersonalization. Weight phobia represents a person's concern about weight and obesity, and body image concerns the physical appearance. Avoidance is a body image problem that leads to avoidance behavior. Compulsive self-monitoring is the obsessive checking of the physical appearance, and depersonalization is the feeling of being detached from one's body. Jannah 
(2016) found a reliability test result of $0.706-0.862$ for all five factors. According to Kaplan and Saccuzo (2005), the coefficient value of $0.7-0.8$ was representing a good reliability. BUTA uses a 6-Likert-scale in which " 0 " indicates "never," "1" indicates "rare," "2" indicates "sometimes," "3" indicates "frequent," "4" indicates "very often," and " 5 " indicates "always." The cutoff score of BUT-A was 1.2, meaning that if participants scored above 1.2, they were said to be dissatisfied with their bodies.

\section{Validity Test}

A validity test was performed using both tests collected among 31 respondents, and a calculation of validity was done using SPSS version 23. Data was processed using a bivariate Pearson correlation and obtained a score of 0.719 with a significance level of 0.000 ( $p<$ 0.01). According to Kaplan and Sacuzzo (2005), results with a coefficient value of 0.7-0.8 are categorized as good.

Table I. Bivariate Pearson Correlation Result between Pastas-S and But-A

\begin{tabular}{|l|l|}
\hline $\mathbf{F}$ & $\boldsymbol{p}$ \\
\hline 0.719 & 0.000 \\
\hline & $* * p<0.01$.
\end{tabular}

\section{Procedure}

We conducted a non-experimental study that used a pre- and post-test method. Measurements were performed using the PASTAS-S to determine the effectiveness of the given intervention program. Baseline conditions of body dissatisfaction were determined from pre-test results. Ethical approval was obtained prior to the data collection from the Ethics Committee Faculty of Universitas Indonesia Psychology Department.

Prior to the participants' selection, a survey was conducted among young adult women containing questions related to satisfaction with body perception and the level of needs for psychological intervention to address the problem. The survey consisted of a Google form and was announced by WhatsApp on July 27, 2017. Seventy-eight respondents filled out the form, and $50 \%$ of them expressed dissatisfaction with their body. Thirty percent (12 participants) of them felt the need for psychological intervention. Among those 12, five were willing to attend the group intervention, the timing of which was based on the participants' schedules. The participants were not given rewards during the course of this research, but they had a snack and drink at the end of each face-to-face meeting. In the first meeting, before the intervention began, each participant was asked to fill out the PASTAS-S questionnaire to determine her initial level of body dissatisfaction. The participants were also required to fill out the informed consent form. Table 2 explains the treatment procedure. 
Table II. The Description of the Treatment Procedure

\begin{tabular}{|c|c|c|c|}
\hline Session & Activity & Aim & Time \\
\hline Pre-session & $\begin{array}{l}\text { Completed demographic } \\
\text { data, pre-test, and } \\
\text { informed consent. }\end{array}$ & $\begin{array}{l}\text { To collect the base-line } \\
\text { data from each } \\
\text { participant. }\end{array}$ & 15 minutes. \\
\hline Session 1 & $\begin{array}{l}\text { Introduction, building } \\
\text { rapport, telling story, and } \\
\text { metaphor. }\end{array}$ & $\begin{array}{l}\text { To collect information } \\
\text { related to body } \\
\text { dissatisfaction. }\end{array}$ & 90 minutes. \\
\hline Session 2 & $\begin{array}{l}\text { Diffusion through story } \\
\text { sharing and metaphor, } \\
\text { practicing one } \\
\text { mindfulness skill, and } \\
\text { homework (filled out } \\
\text { ABC's worksheet) }\end{array}$ & $\begin{array}{l}\text { Participants learned to } \\
\text { accept their } \\
\text { experiences and their } \\
\text { emotions in the past } \\
\text { and learned a new } \\
\text { mindfulness skill to } \\
\text { enhance their } \\
\text { sensitivity toward their } \\
\text { thoughts and feelings. }\end{array}$ & 90 minutes. \\
\hline Session 3 & $\begin{array}{l}\text { (1) Acceptance through } \\
\text { mindfulness activity } \\
\text { (mindful eating, } \\
\text { breathing, mirror, } \\
\text { physical sensation, } \\
\text { emotion). (2) } \\
\text { Homework: practice two } \\
\text { mindful skills. }\end{array}$ & $\begin{array}{l}\text { To teach participants } \\
\text { the mindfulness } \\
\text { skills and enhance their } \\
\text { sensitivity toward their } \\
\text { thoughts and feelings } \\
\text { related to body } \\
\text { dissatisfaction. }\end{array}$ & 90 minutes. \\
\hline Session 4 & $\begin{array}{l}\text { (1) Practice mindfulness } \\
\text { skills and set goal, value, } \\
\text { and write down a } \\
\text { commitment. (2) } \\
\text { Termination. }\end{array}$ & $\begin{array}{l}\text { Help participants to } \\
\text { map out their important } \\
\text { goals and values in } \\
\text { their lives and } \\
\text { encourage them to } \\
\text { commit doing } \\
\text { the action to reach their } \\
\text { goals and values. }\end{array}$ & 90 minutes. \\
\hline Post-test & $\begin{array}{c}\text { Filled out the PASTAS- } \\
\text { S scale. }\end{array}$ & $\begin{array}{l}\text { To collect information } \\
\text { regarding } \\
\text { the effectiveness of the } \\
\text { intervention program. }\end{array}$ & 15 minutes. \\
\hline
\end{tabular}

\section{Participants Information}

The participants included were three master students and two undergraduate students. They ranged in age from 20 to 26 years, three of them were overweight, one was underweight, and one had a normal weight. 
Table III. Participants' Informations

\begin{tabular}{|l|l|l|l|l|l|}
\hline \multicolumn{1}{|c|}{ Name } & \multicolumn{1}{c|}{ RI } & \multicolumn{1}{c|}{ KHD } & \multicolumn{1}{c|}{ IS } & \multicolumn{1}{c|}{ DI } & \multicolumn{1}{c|}{ NB } \\
\hline Age & 25 & 26 & 25 & 20 & 20 \\
\hline Height & 154 & 165 & 155 & 166 & 164 \\
\hline Weight & 63 & 72 & 38 & 72 & 67 \\
\hline BMI & 26.56 & 26.44 & 15.81 & 26.13 & 24.91 \\
\hline Status & $\begin{array}{l}\text { Master } \\
\text { student }\end{array}$ & $\begin{array}{l}\text { Master } \\
\text { Student }\end{array}$ & $\begin{array}{l}\text { Master } \\
\text { Student }\end{array}$ & $\begin{array}{l}\text { Undergrad } \\
\text { uate } \\
\text { student }\end{array}$ & $\begin{array}{l}\text { Undergra } \\
\text { duate } \\
\text { student }\end{array}$ \\
\hline $\begin{array}{l}\text { Informa } \\
\text { tion }\end{array}$ & Overweight & $\begin{array}{l}\text { Over } \\
\text { weight }\end{array}$ & $\begin{array}{l}\text { Under } \\
\text { weight }\end{array}$ & $\begin{array}{l}\text { Over } \\
\text { weight }\end{array}$ & Normal \\
\hline
\end{tabular}

*There was different history in each participant (table 3).

Table IV. Participants' Case History

\begin{tabular}{|c|c|c|}
\hline $\begin{array}{l}\text { Participant } \\
\text { (Initials) }\end{array}$ & $\begin{array}{c}\text { Precipitating Factors in the } \\
\text { Present }\end{array}$ & Precipitating Factors in the Past \\
\hline RI & $\begin{array}{l}\text { Weight gained up to } 10 \mathrm{~kg} \text {. She } \\
\text { felt that she was on the fattest } \\
\text { condition. (2) Comments from } \\
\text { friends and her boyfriend related } \\
\text { to body shape. }\end{array}$ & $\begin{array}{l}\text { Bullied by a boy that she liked when } \\
\text { she was a teenager because of her } \\
\text { fat body. }\end{array}$ \\
\hline KHD & $\begin{array}{l}\text { Comments related to body shape } \\
\text { from a boy who tried to get close } \\
\text { to her. (2) Constant comments } \\
\text { from her college friends in her } \\
\text { master studies. }\end{array}$ & $\begin{array}{l}\text { Labelled as "fat girl" by college } \\
\text { friends during her master studies. }\end{array}$ \\
\hline IS & $\begin{array}{l}\text { Felt exhausted with comments } \\
\text { from others about her } \\
\text { underweight condition. }\end{array}$ & $\begin{array}{l}\text { During her master studies, a lecturer } \\
\text { and her college friends told that her } \\
\text { body appearance was that of a } \\
\text { teenager. That will decrease her } \\
\text { credibility in front of clients. }\end{array}$ \\
\hline DI & $\begin{array}{l}\text { Comments from her older } \\
\text { brother who said that she was } \\
\text { fat. (2) Comments from friends } \\
\text { and others who said that she was } \\
\text { fat. (3) She actively joined the } \\
\text { sports club at college but she } \\
\text { always lacked confidence when } \\
\text { using short sports pants. }\end{array}$ & $\begin{array}{l}\text { During elementary school, most of } \\
\text { her friends were hostile toward her. } \\
\text { She felt that it happened because her } \\
\text { body was ugly. From that moment } \\
\text { on, she hated her body shape. }\end{array}$ \\
\hline NB & $\begin{array}{l}\text { Dislikes her own body because it } \\
\text { is too big. (2) Comments related } \\
\text { to her body shape from her old } \\
\text { friends when reunited. ( } 3 \text { ) } \\
\text { Comments from friends and her } \\
\text { boyfriend related to her body } \\
\text { shape. }\end{array}$ & $\begin{array}{l}\text { Since her third year of elementary } \\
\text { school, she has been labelled as } \\
\text { "fat" and "looks like a boy." Those } \\
\text { labels created her self-concept of } \\
\text { being "fat girl." }\end{array}$ \\
\hline
\end{tabular}




\section{Result}

\section{Sessions}

The face-to-face meetings were initially planned to last three sessions, but it took six meetings to complete the study. DI and NB could not attend the second and third scheduled meetings, while RI could not attend the last scheduled meeting.

Table V. Intervention Schedule

\begin{tabular}{|c|c|c|c|c|c|c|}
\hline Information & Meeting 1 & \multicolumn{3}{|c|}{ Meeting 1} & \multicolumn{2}{|c|}{ Meeting 1} \\
\hline Plan & $\begin{array}{c}\text { Septembe } \\
\text { r, } 30\end{array}$ & & October, & & Octo & er, 14 \\
\hline Actual & $\begin{array}{l}\text { Septembe } \\
\text { r, } 30\end{array}$ & $\begin{array}{c}\text { Octobe } \\
\text { r, } 5\end{array}$ & $\begin{array}{c}\text { October } \\
, 10\end{array}$ & $\begin{array}{c}\text { October } \\
, 12\end{array}$ & October & $\begin{array}{c}\text { October } \\
, 20\end{array}$ \\
\hline Participants & $\begin{array}{c}\text { KHD, RI, } \\
\text { IS, DI, } \\
\text { NB }\end{array}$ & $\begin{array}{l}\text { KHD, } \\
\text { RI, IS }\end{array}$ & NB & DI & $\begin{array}{l}\text { KHD, } \\
\text { RI, IS }\end{array}$ & DI, NB \\
\hline
\end{tabular}

\section{Participants Attitude}

During the meetings, all participants were quite active in following the sessions, although there was one participant who was less able to follow instructions during mindful eating and refused to do mindful mirroring. Some participants also could not attend the previously scheduled sessions they had agreed to, and the face-to-face meetings were not running as scheduled. Besides, most participants did not complete the assignment given at the end of each session. This attitude indicated a lack of readiness and commitment from the participants to change and accept the conditions they experienced.

\section{Measurement Result}

Two of the participants had one or more score differences between the pre- and post-test, one participant had above 0.5 score differences, and two others had under 0.5 score differences. The higher the pre-test score, the higher the score differences between the pre- and post-tests.

Table VI. Results of The Pre- and Post-Tests Using PASTAS-S

\begin{tabular}{|l|l|l|l|}
\hline $\begin{array}{l}\text { Initial } \\
\text { Name }\end{array}$ & Pre-Test & Post-Test & $\begin{array}{c}\text { Deviation } \\
\text { Score }\end{array}$ \\
\hline RI & 2.94 & 1.75 & $\mathbf{1 . 1 9}$ \\
\hline KHD & 2.5 & 1.5 & $\mathbf{1}$ \\
\hline IS & 1.25 & 1.12 & $\mathbf{0 . 1 3}$ \\
\hline DI & 1.68 & 0.875 & $\mathbf{0 . 8 0 5}$ \\
\hline NB & 1.43 & 1.12 & $\mathbf{0 . 3 1}$ \\
\hline
\end{tabular}

There was a difference in the PASTAS-S scores between the pre- and post-tests; the post-test scores were lower than the pre-test scores. It can be said that there was a decrease in the body dissatisfaction level though the drop of IS score. It can conclude that body dissatisfaction complaints in young adult women can be reduced by applying the Brief-ACT intervention in a group session. 


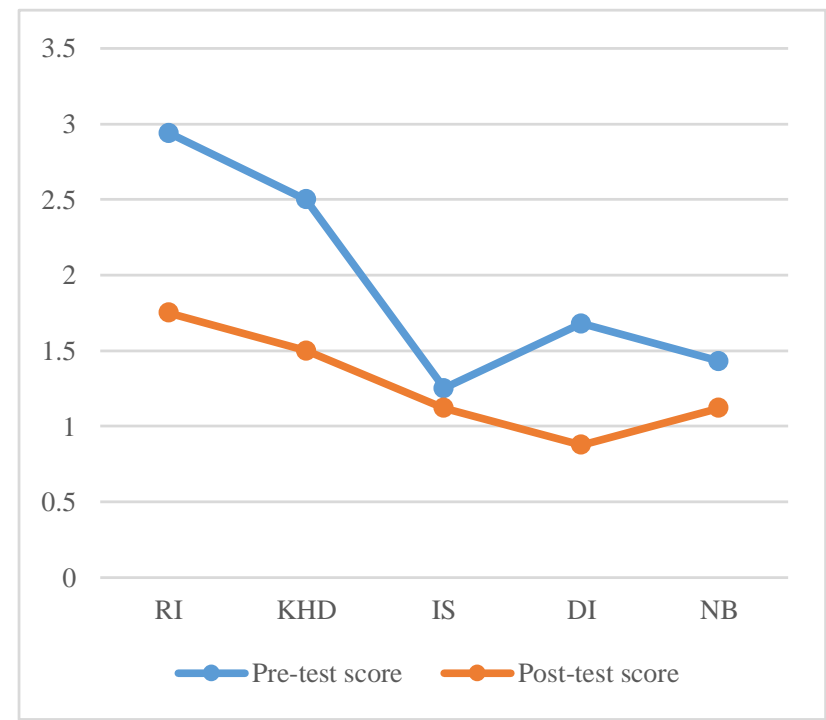

Fig 1. Graphics Score on Pre and Post-Test Using PASTAS-S.

\section{Discussion and Conclusion}

Our five participants who participated in four sessions showed a decrease in their body dissatisfaction level, illustrating that Brief-ACT in a group session helped lower body dissatisfaction levels in young adult women. This finding is in line with previous studies from Pearson and Follete (2009). Results of meta-analysis on six ACT effectiveness studies for body dissatisfaction showed that four studies found ACT to be effective in reducing body dissatisfaction (Griffiths, Williamson, Zucchelli, Paraskeva, \& Moss, 2018). The metaanalysis also argued that the psychological flexibility in ACT helps facilitate a decrease in body dissatisfaction. It cannot be definitively stated whether ACT is truly effective in decreasing body dissatisfaction because researchers used a variety of sessions.

Of the five participants, a higher decrease was observed in RI and KHD (the difference between the PASTAS-S scores for the pre- and post-tests was 1 or more), a moderate decrease in DI (above 0.5), and a slight decrease in the participants IS and NB (less than 0.5 out of 4 ). This allowed us to conclude that this intervention would be effective for participants with above-average BMI as well as with minimum early moderate anxiety levels. These findings were consistent with those from Pearson, Follete, and Hayes (2012), suggesting that BriefACT conducted in less than one-day workshops was effective to reduce body dissatisfaction levels in women with above-average BMI and above-average early anxiety levels. another study conducted by Lillis et al. (2009) found a similar result; a Brief-ACT workshop held in less than one day could reduce weight-related stigma.

The participants IS and NB showed a small decrease in the body dissatisfaction levels. From the calculation of the BMI scores, it was known that IS has a BMI score below mean while NB has a BMI score in the normal range. ACT was effective to decrease body dissatisfaction levels (Pearson, Follette, \& Hayes, 2012) and weight self-stigma (Levin, Potts, Haeger, \& Lillis, 2018) in women with above-average BMIs (Palmeira, Pinto-Gouveia, \& Cunha, 2017). This result supported the idea that Brief-ACT was only effective to reduce body dissatisfaction 
among women with above-average BMIs (the effectiveness of ACT in reducing body dissatisfaction levels related to underweight conditions has heretofore not been studied). This finding was also supported by Calzo et al.'s (2013), who found that body dissatisfaction related to being underweight was only found in men. Furthermore, women were only found to have body dissatisfaction if they have a BMI above the $50^{\text {th }}$ percentile. IS and NB were known to have a low initial anxiety level (PASTAS-S score below 2), further supporting the notion that Brief-ACT is only effective to reduce body dissatisfaction among participants with minimal early moderate anxiety scores. Both conditions (above-average BMI and aboveaverage anxiety levels) were similar to the participant's baseline conditions selected in the study by Pearson et al. (2012). This result was also supported by a the relatively moderate decreased score in the participant DI, whose BMI was above average and whose initial PASTAS-S score was in the low-anxiety range (baseline score below 2).

This research has the following limitations: (1) the number of meetings was not sufficient (only three meetings that contained four sessions) and did not meet the total number of hours (eight) suggested by a previous module - according to Neukrug (2013), group intervention should be implemented in eight meetings minimum; (2) the module used was a module designed for one-day workshop activities, while in this study the intervention was held in three meetings on different days. Those situations possibly affected the acceptance process. The one-week or longer (no more than two weeks) intervals between sessions may have affected the mastery level of previously taught skills as some participants did not get the assignments done. Most of the participants did not fulfill either the $A B C$ worksheet or completed the exercise on mindfulness skills. At the beginning of the second and third sessions, the facilitator always asked if they had the assignment done, and only one participant consistently completed her homework. Brief-ACT may be only effective if implemented in a one-day workshop; (3) the difficulty of arranging schedules and the lack of commitment among the participants; (4) the facilitators had no prior experience in implementing ACT intervention techniques. According to Pearson, Heffner, and Follete (2010), in order to optimize results, Brief-ACT activities should be led by facilitators who already have expertise in using ACT interventions; (5) this study is a non-experimental study, therefore we did not control another variable related to body dissatisfaction. The decrease of score at the end of the study may not be caused entirely by the intervention; other situations in the participants' lives could also be contributing factors; (6) follow-up sessions were not performed in this study, so information regarding how long the changes lasted for was not obtained.

In order to obtain a better result, it is advisable to consider the following points in future research: (1) selecting participants who meet the criteria (having above-average BMI and minimum-medium anxiety score); (2) establishing a clear schedule early on before the intervention activities begin; (3) having the activity led by a facilitator who has mastered ACT intervention techniques; (4) adjusting the implementation time of the activity to the design of the dissertation from Pearson and Follete (2009), which was held in the form of one-day eighthour workshops; (5) adjusting the duration during the separated session to the previous module (eight hours in total). In the present study, facilitators often had to eliminate discussion activities due to the limited time the venue was available; (6) conducting follow-up sessions in 
order to gather valid research results that can be claimed as effective; and (7) increasing the number of participants in order to generalize the results. The intervention aims to target body image flexibility as a mediator between body dissatisfaction and body appreciation that affect regulation skill (Webb, 2014; Webb, Butler-Ajibade, \& Robinson, 2014).

\section{Disclosure Treatment}

The content of this paper has not been published or submitted for publication prior to this and is not under deliberation for publication anywhere. This paper has been reviewed by all authors and those authors have contributed for it in a meaningful way. No potential conflict of interest was reported by the authors.

\section{References}

Blashill, A. J., Williams, A., Grogan, A., \& Clark-Carter, D. (2015). Negative appearance evaluation is associated with skin cancer risk behaviors among American men and women. Health Psychology, 34(1), 93-96.

Bucchianeri, M. M., Arikian, A. J., Hannan, P. J., Eisenberg, M. E., \& Neumark-Sztainer, D. (2013). Body dissatisfaction from adolescence to young adulthood: Findings from a 10-year longitudinal study. Body Image, 10(1), 1-7.

Bucchianeri, M. M. \& Neumark-Sztainer, D. (2014). Body dissatisfaction: An overlooked public health concern. Journal of Public Mental Health, 13(2), 64-69.

Calzo, J. P., Sonneville, K. R., Haines, J., Blood, E. A., Field, A. E., Austin, S. B. (2012). The development of associations among body mass index, body dissatisfaction, and weight and shape concern in adolescent boys and girls. Journal of Adolescent Health, 51(5), 517-523.

Cuzzolaro, M., Veteone, G., Marano, G., \& Garfinkel, P. E. (2006). The body uneasiness test (BUT): Development and validation of a new body image assessment scale. Eating Weight Disorder-Studies on Anorexia, Bulimia and Obesity, 11(1), 1-13.

Erickson, E. H. (1975). Life History and the Historical Moment. New York: Norton.

Griffiths, C., Williamson, H., Zucchelli, F., Paraskeva, N., \& Moss, T. (2018). A Systematic Review of the Effectiveness of Acceptance and Commitment Therapy (ACT) for Body Image Dissatisfaction and Weight Self-Stigma in Adults. Journal of Contemporary Psychotherapy, 1-16.

Grogan, S. (2016). Body image: understanding body dissatisfaction in men, women, and children $3^{\text {rd }}$ edition. London: Routledge.

Hayes, S. C. \& Strosahl, K. D. (2004). A practical guide to acceptance and commitment therapy. New York: Springer Science+Business Media.

Hayes, S. C., Strosahl, K. D., \& Wilson, K. G. (2003). Acceptance and commitment therapy: An Experiential Approach to Behavior Change.

Jannah, P. M. (2016). Ketidakpuasan terhadap tubuh dan komitmen religius pada perempuan muslim berhijab dan tidak berhijab (Body dissatisfaction and religious commitment among muslim female with and without hijab). (Unpublished undergraduate's mini thesis). Depok: Universitas Indonesia.

Jonstang, I. C. (2009). The effect of body dissatisfaction on eating disorder symptomatology: mediating effects of depression and low self-esteem: a partial test of the Dual-Pathway Model. (Master thesis). Department of Psychology, Universitetet i Oslo.

Kaplan, R. M. \& Saccuzo, D. P. (2005). Psychological Testing: Principals, Applications, and Issues (6th Ed.). Australia: Thomson Wadsworth.

Kerlinger, F. N. \& Lee, H. B. (Eds.). (2000). Foundations of Behavioral Research. Orlando, FL: Harcourt College Publishers. 
Levin, M. E., Potts, S., Haeger, J., \& Lillis, J. (2018). Delivering Acceptance and Commitment Therapy for Weight Self-Stigma Through Guided Self-Help: Results From an Open Pilot Trial. Cognitive and Behavioral Practice, 25(1), 87-104.

Lillis, J., Dahl, J., \& Weineland, S. M. (2014). The diet trap: Feed your psychological needs and end the weight loss struggle using acceptance and commitment therapy. Oakland: New Harbinger Publications.

Lillis, J., Hayes, S. C., Bunting, K., \& Masuda, A. (2009). Teaching acceptance and mindfulness to improve the lives of the obese: A preliminary test of a theoretical model. Annals of Behavioral Medicine, 37(1), 5869.

Neukrug, E. D. (2013). Theory, practice, and trends in human services: an introduction. USA: Brooks/ Cole Cengage Learning.

Niide, T. K., Davis, J., Alice, M. T., Derauf, C., Harrigan, R. C., \& Yates, A. (2011). Body ideals and body dissatisfaction among a community sample of ethnically diverse adolescents on Kauai, Hawaii. Hawaii Journal of Public Health, 3(1), 1-7.

Palmeira, L., Pinto-Gouveia, J., \& Cunha, M. (2017). Exploring the efficacy of an acceptance, mindfulness \& compassionate-based group intervention for women struggling with their weight (Kg-Free): A randomized controlled trial. Appetite, 112, 107-116.

Pearson, A. N. \& Follette, V. M. (2009). Acceptance and commitment therapy (ACT) as a workshop intervention for body dissatisfaction and disordered eating attitudes. University of Nevada: Reno.

Pearson, A. N., Follette, V. M., \& Hayes, S. C. (2012). A Pilot Study of Acceptance and Commitment Therapy as a Workshop Intervention for Body Dissatisfaction and Disordered Eating Attitudes. Cognitive and Behavioral Practice, 19(1), 181-197.

Pearson, N. A., Heffner, M., \& Follette, M. (2010). Acceptance and commitment therapy for body image dissatisfaction: A practitioner's guide to using mindfulness, acceptance and values-based behavior change strategies. Oakland, CA: New Harbinger Publications.

Powers, M. B., Vörding, M. B. Z. V. S., \& Emmelkamp, P. M. (2009). Acceptance and commitment therapy: A meta-analytic review. Psychotherapy and psychosomatics, 78(2), 73-80.

Quick, V., Eisenberg, M. E., Bucchianeri, M. M., \& Neumark-Sztainer, D. (2013). Prospective predictors of body dissatisfaction in young adults: 10-year longitudinal findings. Emerging Adulthood, 1(4), 271-282.

Reed, D. L., Thompson, J. K., Brannick, M. T., \& Sacco, W. P. (1991). Development and validation of the physical appearance state and trait anxiety scale (PASTAS). Journal of Anxiety Disorders, 5(4), 323-332.

Santrock, J. W. (2011). Life span development (13 $3^{\text {th }}$ edition). New York: Mc-Graw Hill.

Showers, C. J., \& Larson, B. E. (1999). Looking at body image: The organization of self-knowledge about physical appearance and its relation to disordered eating. Journal of Personality, 67(4), 659-700.

Substance Abuse and Mental Health Services Administration. (2012). Brief interventions and brief therapies for substance abuse: treatment improvement protocol (TIP) series 34, (SMA) 12 3. Department of Health and Human Services: HHS Publication.

Webb, J. B. (2015). Body image flexibility contributes to explaining the link between body dissatisfaction and body appreciation in White college-bound females. Journal of Contextual Behavioral Science, 4(3), 176183.

Webb, J. B., Butler-Ajibade, P., \& Robinson, S. A. (2014). Considering an affect regulation framework for examining the association between body dissatisfaction and positive body image in Black older adolescent females: Does body mass index matter? Body Image, 11(4), 426-437. 